JIPSINDO No. 1, Volume 3, Maret 2016

\title{
PERSEPSI PESERTA DIDIK TENTANG IMPLEMENTASI PENDEKATAN SAINTIFIK DALAM PEMBELAJARAN IPS DI SMP \\ SE- KECAMATAN KRETEK, BANTUL
}

\section{Taat Wulandari, Agustina Tri Wijayanti}

Pendidikan IPS, Fakultas Ilmu Sosial, UNY

Email: agustina_tw@uny.ac.id, Hp: 085292087344

\begin{abstract}
Abstrak
Tujuan penelitian ini adalah untuk mengetahui persepdi peserta didik tentang implementasi pendekatan saintifik dalam pembelajaran IPS di SMP se-kecamatan Kretek, Bantul. Populasi dan sampel penelitian SMP di kecamatan Kretek, Bantul. Metode penelitian menggunakan survey dengan pendekatan deskritif kuantitatif. Teknik pengumpulan data menggunakan kuesioner sebagai alat pengumpulan data pokok, dan teknik analisis data yang digunakan adalah statistic deskriptif. Hasil penelitian menyimpulkan bahwa peserta didik di SMP Se-kecamatan Kretek memiliki persepsi yang cukup tentang pelaksanaan pendekatan saintifik pada pembelajaran IPS. Hal ini dibuktikan dengan perolehan nilai kategori sangat baik sebesar $7,51 \%$, baik sebesar $30,52 \%$, cukup sebesar $44,13 \%$, kurang baik sebesar 15,96\%, dan sangat kurang baik sebesar $1,88 \%$. Persepsi cukup tersebut menunjukan bahwa peserta didik cukup mampu melaksanakan bentuk kegiatan pembelajaran sesuai dengan pendekatan saintifik yang meliputi mengamati, menanya, mengumpulkan data, mengasosiasikan dan mengkomunikasikan.
\end{abstract}

Kata kunci: Persepsi, pendekatan saintifik, pembelajaran IPS 


\begin{abstract}
The purpose of this study was to determine the perceptions of students about the implementation of the scientific approach in teaching social studies in junior high school districts Kretek, Bantul. Population and sample SMP in the district Kretek, Bantul. The research method used survey with quantitative descriptive approach. The technique of collecting data using questionnaires as the principal means of data collection, and data analysis technique used is descriptive statistics. The study concluded that students in junior Se-districts Kretek have sufficient perception about the implementation of the scientific approach to learning IPS. This is evidenced by the acquisition value excellent category by $7.51 \%$, both amounting to $30.52 \%$, quite by $44.13 \%$, amounting to $15.96 \%$ unfavorable, very unfavorable and amounted to $1.88 \%$. Perception pretty indicates that learners are quite capable of carrying out this kind of learning activities in accordance with the scientific approach that includes observing, ask, collect data, associate and communicate.
\end{abstract}

Keywords: Perception, scientific approach, social studies

\title{
Pendahuluan
}

Penataan pelaksanaan pendidikan terutama kurikulum diperlukan sebagai salah satu upaya untuk mempersiapkan sumber daya manusia yang berkompeten. Pengembangan kurikulum pada tahun ajaran 2013/2014 mulai diimplementasikan kurikulum baru yaitu kurikulum 2013. Melalui implementasi kurikulum 2013 yang berbasis kompetensi sekaligus karakter melalui pendekatan tematik dan kontekstual diharapkan peserta didik mampu secara mandiri meningkatkan dan mengembangkan pengetahuannya sehingga dapat diterapkan di kehidupan sehari-hari. Berkaitan dengan itu, munculnya kurikulum 2013 membawa permasalahan tersendiri dalam dunia pendidikan. Menteri Pendidikan dan Kebudayaan Anis Baswedan, P.hD mengatakan bahwa perlu ada kesiapan dari guru, 
kepala sekolah siswa, sistem penilaian, buku siswa dalam mengimplementasikan kurikulum ini.

Perbedaan implementasi kurikulum 2013 dengan kurikulum KTSP membawa pengaruh pada proses pembelajaran di dalam kelas maupun di luar kelas. Proses pembelajaran yang diterapkan dalam kurikulum 2013 menekankan pada dimensi pedagogic modern, yaitu menggunakan pendekatan ilmiah (scientific) yang memusatkan kegiatan pembelajaran pada aktifitas peserta didik untuk dapat membangun konsep yang baru. Pada kurikulum 2013 terdapat lima tahapan yaitu mengamati, menanya, mengumpulkan data/informasi, mengasosiasi dan mengkomunikasikan. Adapun pada kurikulum KTSP proses pembelajaran ditekankan pada tahapan elaborasi, eksplorasi, konformasi.

Keberhasilan proses pembelajaran dengan pendekatan saintifik tidak hanya ditentukan oleh guru tetapi juga peserta didik. Peserta didik diarahkan agar dapat membangun konsep dan pemahaman baru secara mandiri melalui kegiatan ilmiah seperti diskusi yang dibimbing oleh guru. Proses pembelajaran melalui metode diskusi dalam pendekatan saintifik mempunyai pengaruh dan persepsi bagi peserta didik. Menurut Bimo Walgito (2010: 103) bahwa persepsi berawal dari memilih stimulus yang diterima individu, individu menyadari dan memberikan respon sebagai reaksi terhadap stimulus. Kegiatan pembelajaran dengan pendekatan saintifik merupakan stimulus yang diterima oleh peserta didik dan respon yang ditunjukkan peserta didik adalah kelanjutan dari proses persepsi. Beberapa permasalahan muncul dalam pembelajaran IPS di SMP khususnya di Kecamatan Kretek seiringan dengan penerapan pendekatan saintifik. 
Berdasarkan hasil wawancara dengan guru dan observasi, permasalahan yang muncul dalam penerapan pendekatan saintifik adalah guru kurang memahami langkah-langkah pembelajaran menggunakan pendekatan saintifik, peserta didik terlihat bingung ketika diminta guru untuk menyelesaikan tugas secara mandiri, selain itu kurang aktifnya siswa juga berpengaruh pada proses pembelajaran di kelas. Sehingga, persepsi peserta didik terkait dengan proses pembelajaran sangat beragam yang dapat berpengaruh dalam rangka membangun konsep awal peserta didik terkait dengan materi pelajaran. Pada dasarnya, persepsi awal yang baik akan mendorong peserta didik bisa lebih aktif memberikan tanggapan dalam pembelajaran melalui pendekatan saintifik.

Persepsi peserta didik tentang pendekatan saintifik dalam pembelajaran IPS bisa menjadi salah satu indikator apakah pendekatan saintifik di SMP efektif untuk diterapkan. Sehingga, perlu dilakukan penelitian yang akan mengetahui persepsi peserta didik tentang implementasi pendekatan saintifk dalam pembelajaran IPS di SM se-Kecamatan Kretek, Bantul?

\section{Pengertian Persepsi}

Menurut Slameto (2003: 102) persepsi merupakan proses yang menyangkut masuknya pesan atau informasi ke dalam otak manusia sehingga terus menerus terjalin hubungan dengan lingkungannya. Proses hubungannya melalui indera seperti indera penglihatan, pendengar, peraba dan pencium. Wibowo (2014: 60) menjelaskan bahwa persepsi merupakan peroses yang memungkinkan kita mengorganisir informasi dan mengintepretasikan kesan terhadap lingkungan sekitanya. Pendapat lain dari Bimo Walgito (2010: 99), persepsi merupakan proses yang didahului oleh penginderaan yaitu 
proses diterimanya stimulus melalui alat reseptornya. Proses persepsi tidak hanya berhenti pada proses penerimaan stimulus, melainkan stimulus diteruskan ke pusat susunan syaraf yaitu otak dan terjadilah proses psikologis sehingga individu menyadari apa yang ia lihat atau dengar. Penginderaan tidak lepas dari proses persepsi dan proses pendahulu persepsi.

Berdasarkan pendapat para ahli, dapat disimpulkan bahwa persepsi merupakan proses kognisi untuk menyederhanakan, menyaring, menginterpretasikan suatu informasi atau stimulus yang diterima oleh sistem penginderaan sehingga memunculkan kesan terhadap lingkungan sekitarnya. Sehingga, persepsi peserta didik meruapak proses dimana peserta didik menerima, mengorganisir dan menerjemahkan stimulus sehingga peserta didik menyadari, mengetahui dan mendapat pengalaman dari kondisi lingkunganya termasuk implementasi pembelajaran IPS menggunakan pendekatan saintifik.

Proses terjadinya persepsi menurut Bimo Walgito (2010: 102), meliputi:

1. Proses ke-alaman (fisik) yaitu proses saat objek menimbulkan stimulus dan mengenai alat indera atau reseptor. Proses ini merupakan awal proses persepsi.

2. Proses fisiologi, yaitu proses yang terjadi di otak atau pusat kesadaran, sehingga individu dapat menyadari apa yang ia terima dengan alat indera atau resptor.

Beberapa faktor yang dapat mempengaruhi persepsi menurut Miftah Thoha (149-156): 
1. Faktor internal :

a. Proses belajar (learning), semua faktor dari dalam yang membentuk adanya perhatian kepada suatu objek sehingga menimbulkan adanya persepsi yang didasarkan pada kekomplekan jiwa.

b. Motivasi, sesuatu yang diinginkan atau dibutuhkan seseorang akan menarik perhatian dan lebih menimbulkan motivasi. Motivasi dan kepribadian tidak dapat dipisahkan dari bagian proses belajar.

c. Kepribadian, dalam membentuk persepsi unsur kepribadian sangat erat hubungannya dengan proses belajar dan motivasi, yang mempunyai akibat tentang apa yang diperhatikan dalam menghadiri suatu situasi.

2. Faktor eksternal:

a. Intensitas, prinsip intensitas dari suatu perhatian dapat dinyatakan bahwa semakin besar intensitas stimulus dari luar, semakin besar pula hal-hal yang dapat dipahami.

b. Ukuran, semakin besar ukuran suatu objek, maka semakin mudah untuk bias dipahami.

c. Keberlawanan atau kontras, prinsip ini menyatakan bahwa stimulus luar yang penampilannya berlawanan dengan latar belakang atau sama sekali di luar sangkaan orang banyak menarik perhatian.

d. Pengulangan, bahwa stimulus dari luar yang diulang akan memberikan perhatian yang lebih besar dibandingkan dengan yang sekali dilihat. Pengulangan akan menambah kepekaan kita atau kewaspadaan terhadap stimulus. 
e. Gerakan, prinsip menyatakan bahwa orang akan memberikan banyak perhatian terhadap objek yang bergerak dalam jangkauan pandangan dibandingkan dari objek yang diam.

\section{Pendekatan Saintifik}

Menurut Ridwan Abdullah (2014: 50-51), pendekatan saintifik berkaitan erat dengan metode saintifik yang pada umumnya melibatkan kegiatan pengamatan atau observasi yang dibutuhkan untuk perumusan hipotesisi atau mengumpulkan data yang dilandasi dengan pemaparan data yang diperoleh melalui percobaan. Kegiatan percobaan dapat diganti dengan kegiatan memperoleh informasi dari berbagai sumber. Menurut Abdul Majid (2014: 193), proses pembelajaran dengan pendekatan saintifik dimaksudkan untuk memberikan pemahaman kepada peserta didik dalam menganal, memahami berbagai materi menggunakan pendekatan ilmiah. Pendekatan saintifik juga dimaksudkan untuk memberikan pemahaman bahwa informasi bias berasal dari mana saja, kapan saja dan tidak bergantung pada informasi searah dari guru. Pembelajaran yang berlangsung mendorong peserta didik untuk mencari tahu dar berbagai sumber observasi, bukan diberi tahu.

Kondisi pembelajaran menggunakan pendekatan saintifik diarahkan agar peserta didik mempu merumuskan masalah (menanya), bukan hanya menyelesaikan masalah dengan menjawab. Proses pembelajaran diarahkan untuk melatih berpikir analitis (diajarkan bagaimana mengambil keputusan) bukan berpikir mekanistis (rutin dengan hanya mendengarkan dan menghapal saja). Kondisi pembelajaran yang demikian pada akhirnya akan menumbuhkan kemampuan berpikir tingkat tinggi peserta didik. 
Langkah-langkah dalam pendekatan saintifik dapat di lihat dalam table (Hosnan, 2014: 39):

Tabel 1. Langkah-langkah pendekatan saintifik

\begin{tabular}{|l|l|}
\hline Langkah-langkah & Aktivitas Belajar \\
\hline Mengamati (observing) & $\begin{array}{l}\text { Melihat, mengamati membaca, } \\
\text { mendengar, menyimak (tanpa dan } \\
\text { dengan alat) }\end{array}$ \\
\hline Menanya (questioning) & $\begin{array}{l}\text { Mengajukan pertanyaan dari yang } \\
\text { factual sampai yang bersifat hipotesis: } \\
\text { diawali dengan bimbingan guru sampai } \\
\text { dengan mandiri (menjadi suatu } \\
\text { kebiasaan) }\end{array}$ \\
\hline $\begin{array}{l}\text { Pengumpulan data } \\
\text { (experimenting) }\end{array}$ & $\begin{array}{l}\text { Menentukan data yang diperlukan dari } \\
\text { pertanyaan yang diajukan, menentukan } \\
\text { sumber data (benda, dokumen, buku, } \\
\text { eksperimen, mengumpulkan data. }\end{array}$ \\
\hline $\begin{array}{l}\text { Mengasosiasi } \\
\text { (associating) }\end{array}$ & $\begin{array}{l}\text { Menganalisis data dalam bentuk } \\
\text { membuat kategori, menentukan } \\
\text { hubungan data/kategori, menyimpulkan } \\
\text { dari hasil analisis data dimulai dari } \\
\text { unstructured uni structure-multistructure- } \\
\text { complicated structure }\end{array}$ \\
\hline $\begin{array}{l}\text { Mengkomunikasikan } \\
\text { (communicating) }\end{array}$ & $\begin{array}{l}\text { Menyampaikan hasil konseptualisasi } \\
\text { dalam bentuk lisan, tulisan, diagaram, } \\
\text { bagan, gambar dan media lainnya. }\end{array}$ \\
\hline
\end{tabular}

Menurut Ridwan Abdullah (2014: 54-72) aktifitas yang

dilakukan dalam pembelajaran saintifik adalah:

1. Melakukan pengamatan atau observasi

Observasi merupakan cara menggunakan panca indera untuk memperoleh informasi tentang karakteristik suatu benda. Pengamatan dapat dilakukan secara kualitatif dan kuantitatif.

2. Mengajukan pertanyaan

Peserta didik perlu dilatih untuk merumuskan pertanyaan terkait dengan topil yang akan dipelajari. Aktofotas ini penting untuk meningkatkan keingintahuan dalam diri peserta didik 
dan mengembangkan kemampuan untuk belajar sepanjang hayat. Peserta didik mampu menysusun pertanyaan yang bermakna akan terbiasa untuk berpikir analitis.

3. Mencoba atau mengumpulkan data

Guru dapat menugaskan peserta didik untuk mengumpulkan data atau informasi dari berbagai sumber. Pembelajaran IPS pada umumnya membutuhkan data dan informasi yang diperoleh berdasarkan wawancara, survey pendapat, pengamatan. Komponen mencoba dalam kasus ini mencoba untuk berkomunikasi, mencoba berperan dalam sebuah situasi sosial.

4. Mengasosiasi atau menalar

Menalar adalah aktivitas mental khusus dalam melakukan inferensi. Inferensi adalah menarik kesimpulan berdasarkan pendapat, data, fakta dan informasi. Penalaran empiris didasarkan pada logika induktif yaitu menalar dari hal khusus ke umum, sedangkan penalaran induktif menggunakan bukti khusus seperti fakta, data, informasi, pendapat dari ahli.

5. Mengkomunikasikan

Kemampuan untuk emmbangun jaringan dan berkomunikasi perlu dimiliki peserta didik karena kompetensi tersebut sama pentingnya dengan pengetahuan, ketrampilan dan pengalaman. Bekerjasama dalam sebuah kelompok merupakan salah satu cara kemampuan peserta didik untuk dapat membangun jaringan dan berkomunikasi.

Penerapan pendekatan saintifik dalam pembelajaran melibatkan ketrampilan proses seperti mengamati, mengklasifikasi, mengukur, meramalkan, menjelaskan dan menyimpulkan. Adapun 
karakteristik pendekatan saintifik seperti yang dijelaskan Hosnan (2014: 36) sebagai berikut:

1. Berpusat pada peserta didik

2. Melibatkan ketrampilan proses sains dalam mengkonstruk konsep, hokum dan prinsip

3. Melibatkan proses kognitif yang potensial dalam merangsang perkembangan intelek, khususnya ketrampilan berpikir tingkat tinggi peserta didik

4. Dapat mengembangkan nilai-nilai karakter

Dari pendapat di atas dapat disimpulkan bahwa pembelajaran yang dilaksanakan dengan pendekatan saintifik atau ilmiah memusatkan kegiatannya pada peserta didik agar mampu mengkonstruk konsep secara mandiri yang berlandaskan pada fakta yang bersifat obyektif dan dapat dipertanggungjawabkan. Pembelajaran yang berpusat pada peserta didik akan mendorong peserta didik untuk berpikir kritis dan meningkatkan ketrampilan berpikir tingkat tinggi peserta didik.

\section{Pembelajaran IPS}

Pembelajaran menurut Zamroni (2011: 238) bahwa pembelajaran merupakan interaksi yang melibatkan dua pihak yaitu pendidik dan peserta didik untuk mencapai tujuan yang telah ditentukan, sehingga interaksi komunikasi yang terjadi baik antara sumber belajar, guru dan peserta didik. Pembelajaran IPS merupakan integrasi dari berbagai cabang ilmu sosial seperti sosiologi, sejarah, geografi, ekonomi, politik, hukum dan budaya. Ilmu Pengetahuan Sosial dirumuskan atas dasar realita dan fenomena sosial yang mewujudkan satu pendekatan interdisipliner dari aspek dan cabang ilmu sosial. 
Muhammad Numan Sumantri (2001: 44) menjelaskan tentang IPS di tingkat sekolah merupakan suatu penyederhanaan disiplin ilmu-ilmu sosial, psikologi, filsafat, ideologi negara, dan agama yang diorganisasikan dan disajikan secara ilmiah dan psikologis untuk tujuan pendidikan. Maka mata pelajaran IPS di Indonesia ialah penyederhanaan ilmu-ilmu sosial yang disajikan secara ilmiah dan psikologis yang memiliki tujuan untuk bidang pendidikan.

Berdasarkan berbagai pendekatan yang diungkapkan oleh para ahli, maka pada hakikatnya mata pelajaran IPS untuk tingkat SMP dan MTs adalah integrasi dan penyederhanaan dari berbagai macam displin ilmu-ilmu sosial yang disusun secara sistematis, komprehensif, dan terpadu, dan diharapkan peserta didik dapat memperoleh pemahaman yang lebih luas dan mendalam sehingga mampu menganalisis kondisi masyarakat dan mampu memecahkan permasalahan dalam kehidupan sehari-hari. Menurut Mulyana (2003: 195) bahwa tujuan mata pelajaran IPS agar siswa mampu mengembangakan pengetahuan, nilai sikap serta keterampilan sosial untuk mengembangakan pemahaman tentang pertumbuhan masyarakat. Pendapat lain disampaikan oleh Trianto (2010:176) bahwa tujuan IPS untuk mengembangkan siswa agar peka terhadap masalah sosial yang terjadi dalam masyarakat, memiliki sikap mental yang positif terhadap perbaikan segala ketimpangan yang terjadi, dan terampil mengatasi setiap masalah yang terjadi sehari-hari. Pernyataan tersebut didukung oleh pendapat Supardi (2011: 186187) bahwa tujuan mata pelajaran IPS agar siswa menghayati nilai hidup, nilai moral, kejujuran, dan keadilan. Selain itu siswa dapat mengembangkan kesadaran dan kepedulian terhadap lingkungannya. 


\section{Metode Penelitian}

Desain dalam penelitian ini menggunakan survey dengan pendekatan deskritif kuantitatif. Menurut Masri Singarimbun (1989: 3) penelitian survey merupakan penelitian yang mengambil sampel dari populasi dan menggunakan kuesioner sebagai alat pengumpulan data pokok. Penelitin survey dimaksudkan untuk mendiskripsikan persepsi peserta didik tentang implementasi pendekatan saintifik dalam pembelajaran IPS di SMP se-Kecamatan Kretek, Bantul. Penelitian dilaksanakan di SMP se-Kecamatan Kretek, Kabupaten Bantul dan dimulai bulan April - September 2015.

Populasi dalam penelitian ini adalah seluruh peserta didik SMP kelas VII dan VIII di Kecamatan Kretek. Dipilih populasi penelitian di kelas VII dan VIII karena penerapan pendepatan saintifik di kelas tersebut. Berikut daftar SMP di Kecamatan Kretek. Tabel 2. Daftar peserta didik di SMP se-Kecamatan Kretek

\begin{tabular}{|l|l|c|}
\hline No & Nama Sekolah & Jumlah Peserta didik \\
\hline 1. & SMP Negeri 1 Kretek & 309 \\
\hline 2. & SMP Negeri 2 Kretek & 213 \\
\hline 3. & SMP Muhammadiyah Kretek & 41 \\
\hline & Jumlah & 563 \\
\hline
\end{tabular}

Pengambilan sampel dalam penelitian ini menggunakan teknik Stratified cluster random Sampling atau sampel acak klaster bertrata karena populasi terdiri dari kelas dan klaster yang berbeda.

Dalam penelitian ini, teknik analisis data yang digunakan adalah statistic deskriptif. Menurut Soegiyono (2012: 147) statistic deskriptif adalah statistic yang digunakan untuk menganalisis data dengan cara mendeskripsikan dan menggambarkan data yang telah terkumpul sebagaimana adanya tanpa bermaksud membuat 
kesimpulan yang berlaku untuk umum atau generalisasi. Statistik deskriptif berfungsi untuk mendeskripsikan atau menggambarkan obyek yang diteliti melalui data sampel atau populasi yang ada tanpa membuat kesimpulan yang berlaku umum.

\section{Hasil Penelitian}

Data persepsi peserta didik tentang pelaksanaan pendekatan saintifik pada pembelajaran IPS diperoleh melalui kuesioner yang terdiri dari 53 item dengan jumlah responden 213 peserta didik. Terdapat 5 alternatif jawaban dimana skor tertinggi adalah 5 dan skor terendah adalah 1. Deskripsi data pada penelitian ini meliputi nilai Mean (M), Median (Me), Modus (Mo) dan Standar Deviasi (SD) dari skor angket penelitian.

Berdasarkan data yang telah dikumpulkan diperoleh skor tertinggi sebesar 256 dan skor terendah 162. Adapun hasil perhitungan Mean (M) sebesar 213,4, Median (Me) sebesar 214, Modus (Mo) sebesar 214 dan 58. Standar Deviasi (SD) sebesar 14,118 . Jumlah kelas interval diperoleh dengan menggunakan rumus $\mathrm{k}=1+3,3 \log 213, \mathrm{k}=1+3,3(2,32)=8,66$ dan dibulatkan diperoleh jumlah 9 kelas. Jangkauan kelas atau range $(\mathrm{R})$ diperoleh dari rumus range $=($ data terbesar - data terkecil $)$, range $=(256-162)=94$. Lebar kelas $\mathrm{I}=$ range $/ \mathrm{k}=94 / 9=10,44$ dibulatkan menjadi 10 . Berdasarkan data yang telah dikumpulkan melalui kuesioner dan hasil analisis di atas, maka dapat disajikan distribusi frekuensi skor persepsi peserta didik tentang pelaksanaan pendekatan saintifik.

Diketahui bahwa perolehan skor persepsi peserta didik tentang pelaksanaan pendekatan saintifik dominan pada kelas interval 212 221. Apabila dilihat dari nilai rata-rata/mean juga 59 menunjukan bahwa nilai mean sebesar 213, 4 berada pada kelas interval 212 - 
221. Dapat diketahui pula bahwa selisih frekuensi antara skor tertinggi dan terendah pada persepsi tentang pelaksanaan pendekatan saintifik pada pembelajaran IPS tidak banyak. Skor tertinggi berada pada kelas interval 252 - 261 dengan frekuensi 1 dan skor terendah pada kelas interval 162 - 171 dengan frekuensi 2 . Tahap berikutnya ialah mengelompokan data ke dalam lima kategori yaitu sangat baik, baik, cukup, kurang baik, dan sangat kurang baik. Penentuan kategori didasarkan pada rumus statistik menurut Syaifuddin Azwar (2014: 148-149) dengan nilai Mean Ideal (Mi) sebesar 209 dan nilai Standar Deviasi Ideal (SDi) sebesar 15,67.

Distribusi dan persentase skor kecenderungan persepsi peserta didik tentang pelaksanaan pendekatan saintifik pada pembelajaran IPS dominan pada kelas interval $201,16<\mathrm{X} \leq 216,84$ yaitu sebesar $44,13 \%$ dengan frekuensi sebanyak 94 responden. Apabila dilihat dari nilai mean sebesar 213, 4 juga berada pada kelas interval 201,16 $<\mathrm{X} \leq 216,84$.

Berdasarkan diagram lingkaran di atas dapat diketahui bahwa persepsi peserta didik tentang pelaksanaan pendekatan saintifik pada pembelajaran IPS di SMP Se-Kecamatan Kretek berada pada kategori sangat baik sebesar 7,51\%, baik sebesar 30,52\%, cukup sebesar $44,13 \%$, kurang baik sebesar 15,96\%, dan sangat kurang baik sebesar 1,88\%. Hal ini menunjukan bahwa sebagian besar peserta didik di SMP Se-Kecamatan Kretek memiliki persepsi cukup tentang pelaksanaan pendekatan saintifik pada pembelajaran IPS di SMP. Penyajian hasil penelitian untuk masing-masing indikator persepsi peserta didik tentang pelaksanaan pendekatan saintifik pada pembelajaran IPS di SMP Se-Kecamatan Kretek dijelaskan sebagai berikut: 
Data persepsi peserta didik tentang kegiatan mengamati video, gambar/objek lain, dan penjelasan guru diperoleh melalui kuesioner yang terdiri dari 12 item dengan jumlah responden 213 peserta didik. Terdapat 5 alternatif jawaban dimana skor tertinggi adalah 5 dan skor terendah adalah 1. Diperoleh skor tertinggi sebesar 56 dan skor terendah sebesar 42. Adapun nilai mean (M) sebesar 49,06, median (Me) sebesar 49, modus (Mo) sebesar 49 dan standar deviasi (SD) sebesar 2,921. Jumlah kelas interval $(\mathrm{k})=1+3,3 \log 213, \mathrm{k}=1+$ $3,3(2,32)=8,66$ dan dibulatkan diperoleh jumlah 9 kelas. Jangkauan kelas atau range $(\mathrm{R})$ diperoleh dari rumus range $=$ (data terbesar data terkecil), range $=(56-42)=14$. Adapun lebar kelas $\mathrm{I}=$ range $/ \mathrm{k}=$ $14 / 9=1,56$ dan dibulatkan menjadi 2 .

Perolehan skor persepsi peserta didik tentang kegiatan mengamati dalam pelaksanaan pendekatan saintifik dominan pada kelas interval 48 - 49. Apabila dilihat dari nilai rata-rata/mean juga menunjukan bahwa nilai mean sebesar 49,06 berada pada kelas interval 48 - 49. Dapat diketahui pula bahwa selisih frekuensi antara skor tertinggi dan terendah pada persepsi tentang kegiatan mengamati video, gambar/objek lain, dan penjelasan guru tidak banyak. Skor tertinggi berada pada kelas interval 56 - 57 dengan frekuensi 3 dan skor terendah pada kelas interval $42-43$ dengan frekuensi 4.

Berdasarkan diagram lingkaran di atas dapat diketahui bahwa persepsi peserta didik tentang kegiatan mengamati dalam pelaksanaan pendekatan saintifik di SMP Se-Kecamatan Kretek berada pada kategori sangat baik sebesar 14,55\%, baik sebesar $15,50 \%$, cukup sebesar 39,44\%, kurang baik sebesar $25,35 \%$, sangat kurang baik 5,16\%. Hal ini menunjukan bahwa sebagian besar 
peserta didik di SMP Se-Kecamatan Kretek memiliki persepsi cukup tentang kegiatan mengamati dalam pelaksanaan pendekatan saintifik pada pembelajaran IPS di SMP.

Data persepsi peserta didik tentang kegiatan menanya/menyusun pertanyaan untuk meminta informasi, menyamakan pendapat dalam pelaksanaan pendekatan saintifik diperoleh melalui kuesioner yang terdiri dari 9 item dengan jumlah responden 213 peserta didik. Terdapat 5 alternatif jawaban dimana skor tertinggi adalah 5 dan skor terendah adalah 1 . Diperoleh skor tertinggi sebesar 44 dan skor terendah 21. Adapun nilai mean (M) sebesar 36,37, median (Me) sebesar 37, modus (Mo) sebesar 37 dan Standar Deviasi (SD) sebesar 3,278. Jumlah kelas interval diperoleh dengan menggunakan rumus $\mathrm{k}=1+3,3 \log 213, \mathrm{k}=1+3,3(2,32)=8,66$ dan dibulatkan diperoleh jumlah 8 kelas. Jangkauan kelas atau range $(\mathrm{R})$ diperoleh dari rumus range $=($ data terbesar - data terkecil $)$, range $=(44-21)=23$. Adapun lebar kelas $\mathrm{I}=$ range $/ \mathrm{k}=23 / 9=2,56$ dibulatkan menjadi 3 .

Perolehan skor persepsi peserta didik tentang kegiatan menanya/menyusun pertanyaan untuk meminta informasi atau menanyakan pendapat dalam pelaksanaan pendekatan saintifik dominan pada kelas interval 36 - 38. Apabila dilihat dari nilai ratarata/mean juga menunjukan bahwa nilai mean sebesar 36,37 berada pada kelas interval 36 - 38. Dapat diketahui pula bahwa selisih frekuensi antara skor tertinggi dan terendah pada persepsi tentang kegiatan menanya/menyusun pertanyaan untuk meminta informasi atau menanyakan pendapat dalam pelaksanaan pendekatan saintifik tidak banyak. Skor tertinggi berada pada kelas interval $42-44$ dengan frekuensi 5 dan skor terendah pada kelas interval $21-23$ dengan frekuensi 1 . 
Penentuan kategori didasarkan pada rumus statistik menurut Syaifuddin Azwar dengan nilai Mean Ideal (Mi) sebesar 32,5 dan nilai Standar Deviasi (SDi) sebesar 3,83.

Distribusi dan persentase skor kecenderungan persepsi peserta didik tentang kegiatan menanya/menyusun pertanyaan dalam pelaksanaan pendekatan saintifik pada pembelajaran IPS dominan pada kelas interval $34,41<X \leq 38,25$ yaitu sebesar $45,07 \%$ dengan frekuensi sebanyak 96 responden. Apabila dilihat dari nilai mean sebesar 36,37 juga berada pada kelas interval 34,41<X $\leq 38,25$.

Berdasarkan tabel kecenderungan variabel persepsi peserta didik tentang kegiatan menanya dalam pelaksanaan pendekatan saintifik pada pembelajaran IPS di atas maka dapat digambarkan dalam diagram lingkaran (pie chart) berikut:

Berdasarkan diagram lingkaran di atas dapat diketahui bahwa persepsi peserta didik tentang kegiatan menanya dalam pelaksanaan pendekatan saintifik pada Pembelajaran IPS berada pada kategori sangat baik sebesar $27,23 \%$, baik sebesar $45,07 \%$, cukup sebesar $21,13 \%$, kurang baik sebesar 9,39\%, dan sangat kurang baik 0,94\%. Hal ini menunjukan bahwa sebagian peserta didik di SMP SeKecamatan Kretek memiliki persepsi baik tentang kegiatan menanya/menyusun pertanyaan dalam pelaksanaan pendekatan saintifik pada pembelajaran IPS di SMP.

Data persepsi peserta didik tentang kegiatan mengumpulkan data atau informasi dalam pelaksanaan pendekatan saintifik pada pembelajaran IPS diperoleh melalui kuesioner yang terdiri dari 15 item dengan jumlah responden 213 peserta didik. Terdapat 5 alternatif jawaban dimana skor tertinggi adalah 5 dan skor terendah adalah 1. Berdasarkan data yang telah dikumpulkan diperoleh skor 
tertinggi sebesar 74 dan skor terendah 49. Hasil analisis nilai mean (M) sebesar 59,69, median (Me) sebesar 60, modus (Mo) sebesar 60 dan standar deviasi (SD) sebesar 4,797. Jumlah kelas interval $(\mathrm{k})=1+$ 3,3 $\log 213, \mathrm{k}=1+3,3(2,32)=8,66$ dan dibulatkan diperoleh jumlah 9 kelas. Jangkauan diperoleh dari rumus range $=($ data terbesar - data terkecil), range $=(74-49)=25$. Adapun lebar kelas $\mathrm{I}=$ range $/ \mathrm{k}=25 / 9$ $=2,77$ dibulatkan menjadi 3 .

Data persepsi peserta didik tentang kegiatan mengasosiasi atau kegiatan yang dilakukan oleh peserta didik untuk menilai, membandingkan, menemukan keterkaitan satu informasi dengan informasi lainnya, dan mengambil berbagai kesimpulan diperoleh melalui kuesioner yang terdiri dari 10 item. Jumlah responden 213 peserta didik dan terdapat 5 alternatif jawaban dimana skor tertinggi adalah 5 dan skor terendah adalah 1. Diperoleh skor tertinggi 48 dan skor terendah 28. Nilai mean (M) sebesar 39,94, median (Me) sebesar 40, modus (Mo) sebesar 39 dan standar deviasi (SD) sebesar 3,291. Jumlah kelas interval $(\mathrm{k})=1+3,3 \log 213, \mathrm{k}=1+3,3(2,32)=8,66$ dan dibulatkan diperoleh jumlah 9 kelas. Jangkauan kelas atau range $(\mathrm{R})$ diperoleh dari rumus range $=$ (data terbesar - data terkecil), range $=(48-28)=20$. Adapun lebar kelas $\mathrm{I}=$ range $/ \mathrm{k}=20 / 9=2,22$ dibulatkan menjadi 2 .

Distribusi dan persentase skor kecenderungan persepsi peserta didik tentang kegiatan mengasosiasi/menalar informasi dalam pelaksanaan pendekatan saintifik pada pembelajaran IPS dominan pada kelas interval 39,66 < X $\leq 42,99$ yaitu sebesar 33,80\% dengan frekuensi sebanyak 72 responden. Namun apabila dilihat dari nilai mean sebesar 39,34 berada pada kelas interval 36,33<X $\leq 39,66$, hal ini karena selisih antara frekuensi pada kategori baik dan cukup 
JIPSINDO No. 1, Volume 3, Maret 2016

tidak banyak. Berdasarkan tabel kecenderungan variabel persepsi peserta didik tentang kegiatan mengasosiasi/menalar dalam pelaksanaan pendekatan saintifik pada pembelajaran IPS di atas maka dapat digambarkan dalam diagram lingkaran (pie chart) berikut:

Berdasarkan diagram lingkaran di atas dapat diketahui bahwa persepsi peserta didik di SMP Se-Kecamatan Kretek tentang kegiatan mengasosiasi/menalar informasi dalam pelaksanaan pendekatan saintifik pada pembelajaran IPS berada pada kategori sangat baik sebesar 22,07\%, baik sebesar 33,80\%, cukup sebesar 30,98\%, kurang baik sebesar 10,85\%, dan sangat kurang baik sebesar 2,35\%. Hal ini menunjukan bahwa sebagian besar peserta didik di SMP SeKecamatan Kretek memiliki persepsi baik tentang kegiatan mengasosiasi/menalar informasi dalam pelaksanaan pendekatan saintifik pada pembelajaran IPS di SMP.

Data persepsi peserta didik tentang kegiatan mengomunikasi hasil temuan diperoleh melalui kuesioner yang terdiri dari 7 item dengan jumlah responden 213 peserta didik. Terdapat 5 alternatif jawaban dimana skor tertinggi adalah 5 dan skor terendah adalah 1 . Berdasarkan data yang telah dikumpulkan diperoleh skor tertinggi sebesar 35 dan skor terendah 15. Hasil analisis harga mean (M) sebesar 28,34, median (Me) sebesar 28, modus (Mo) sebesar 27 dan standar deviasi (SD) sebesar 2,949. Jumlah kelas interval diperoleh dengan menggunakan rumus $\mathrm{k}=1+3,3 \log 213, \mathrm{k}=1+3,3(2,32)=$ 8,66 dan dibulatkan diperoleh jumlah 9 kelas. Jangkauan kelas atau range $(\mathrm{R})$ diperoleh dari rumus range $=$ (data terbesar - data terkecil), range $=(35-15)=20$. Adapun lebar kelas $\mathrm{I}=$ range $/ \mathrm{k}=20 / 9=2,22$ dibulatkan menjadi 2 . 
Distribusi dan persentase skor kecenderungan persepsi peserta didik tentang kegiatan mengumpulkan data/informasi dalam pelaksanaan pendekatan saintifik pada pembelajaran IPS dominan pada kelas interval 26,66 < X $\leq 29,99$ yaitu sebesar 46,01\% dengan frekuensi sebanyak 98 responden. Apabila dilihat dari nilai mean sebesar 28,34 juga berada pada kelas interval 26,66 < X $\leq$ 29,99. Persepsi peserta didik tentang kegiatan mengamati dalam pelaksanaan pendekatan saintifik pada pembelajaran IPS berada pada kategori sangat baik sebesar 33,33\%, baik sebesar 46,01\%, cukup sebesar 16,43\%, kurang baik sebesar 2,35\%, dan sangat kurang baik sebesar 1,88\%. Hal ini menunjukan bahwa sebagian besar peserta didik di SMP Se-Kecamatan Kretek memiliki persepsi baik tentang kegiatan mengamati dalam pelaksanaan pendekatan saintifik pada pembelajaran IPS di SMP.

Berdasarkan data hasil penelitian yang diperoleh dari angket yang telah diberikan pada 213 peserta didik di SMP Se-Kecamatan Kretek menunjukan bahwa peserta didik memiliki persepsi cukup tentang pelaksanaan pendekatan saintifik pada pembelajaran IPS. Hal ini diketahui dari hasil persentase pengkatogorian yang menghasilkan data sebagai berikut: sebesar 7,51\% pada kaategori sangat baik, 30,52\% pada kategori baik, 44,13\% pada kategori cukup, 15,96\% pada kategori kurang baik dan 1,88\% pada kategori sangat kurang baik. Persepsi peserta menyangkut proses pembelajaran IPS dengan pendekatan saintifik yang meliputi kegiatan mengamati, menanya, mengumpulkan data, mengasosiasi dan mengomunikasi.

Hal ini dibuktikan dengan data hasil penelitian yang menunjukan bahwa pada persepsi peserta didik tentang kegiatan 
mengamati objek berapa pada kategori cukup dengan persentase sebesar 39,44\%. Adapun persepsi tentang kegiatan mengumpulkan data/informasi dalam pelaksanaan pendekatan saintifik berada pada kategori cukup dengan persentase sebesar 32,39\%. Pembelajaran IPS dengan pendekatan saintifik pada awal pembelajaran dimulai dengan merangsang sikap kritis siswa melalui stimulus berupa gambar, video ataupun objek lain, namun peserta didik belum menunjukan perhatian penuh terhadap objek yang ditunjukan guru. Dalam melaksanakan kegiatan mengumpulkan data/informasi peserta didik merasa belum mampu mencari berbagai sumber secara mandiri secara maksimal. Peserta didik masih terbiasa dengan pembelajaran yang terpusat pada guru dan peserta didik terbiasa menerima materi tanpa mencarinya secara mandiri. Indikator-indikator tersebutlah yang menunjukan bahwa persepsi peserta didik tentang pelaksanaan pendekatan saintifik pada pembelajaran IPS masih dalam kategori cukup.

Berdasarkan hasil analisis data penelitian, peserta didik memiliki persepsi yang cukup tentang kegiatan mengamati gambar, video/objek lain dan penjelasan yang ditunjukan atau diberikan oleh guru. Hal ini ditunjukan dengan hasil kategorisasi yang menunjukan sebesar $14,55 \%$ pada kategori sangat baik, $15,50 \%$ pada kategori baik, 39,44\% pada kategori cukup, 25,35\% pada kategori kurang baik, 5,16\% pada kategori sangat kurang baik. Persepsi yang cukup menunjukan bahwa peserta didik merasa cukup dapat mengikuti dan memahami objek atau penjelasan awal yang diberikan oleh guru.

Selain itu, peserta didik memiliki persepsi yang baik tentang kegiatan menanya/meyusun pertanyaan dalam pelaksanaan pendekatan saintifik pada pembelajaran IPS. Hal ini ditunjukan 
dengan hasil kategorisasi yang menunjukan sebesar 27,23\% pada kategori sangat baik, 45,07\% pada kategori baik, 21,13\% pada kategori cukup, 5,63\% pada kategori kurang baik, dan 0,94\% pada kategori sangat kurang baik. Peserta didik memiliki persepsi yang cukup tentang kegiatan mengumpulkan data/informasi dalam pelaksanaan pendekatan saintifik pada pembelajaran IPS. Hal ini ditunjukan dengan hasil kategorisasi yang menunjukan sebesar $6,57 \%$ pada kategori sangat baik, 14,55\% pada kategori baik, 32,39\% pada kategori cukup, 29,11\% pada kategori kurang baik dan 17,31\% pada kategori sangat kurang baik.

Dalam kegiatan mengasosiasi/menalar informasi dalam pelaksanaan pendekatan saintifik pada pembelajaran IPS, persepsi peserta didik menunjukan sebesar 22,07\% pada kategori sangat baik, 33,80\% pada kategori baik, 30,98\% pada kategori cukup, $10,85 \%$ pada kategori kurang baik dan 2,35\% pada kategori sangat kurang baik. Kegiatan mengkomunikasikan peserta didik memiliki persepsi yang baik dalam pelaksanaan pendekatan saintifik pada pembelajaran IPS. Hal ini ditunjukan dengan hasil kategorisasi yang menunjukan sebesar 33,33\% pada kategori sangat baik, 46,01\% pada kategori baik, 16,43\% pada kategori cukup, 2,35\% pada kategori kurang baik dan 1,88\% pada kategori sangat kurang baik.

\section{Simpulan}

Berdasarkan data yang diperoleh dari hasil analisis yang sudah dilakukan, maka dapat ditarik kesimpulan bahwa sebagian besar peserta didik di SMP Se-kecamatan Kretek memiliki persepsi yang cukup tentang pelaksanaan pendekatan saintifik pada pembelajaran IPS. Hal ini dibuktikan dengan perolehan nilai kategori sangat baik sebesar $7,51 \%$, baik sebesar 30,52\%, cukup sebesar 44,13\%, kurang 
JIPSINDO No. 1, Volume 3, Maret 2016

baik sebesar 15,96\%, dan sangat kurang baik sebesar 1,88\%. Persepsi cukup tersebut menunjukan bahwa peserta didik cukup mampu melaksanakan bentuk kegiatan pembelajaran sesuai dengan pendekatan saintifik yang meliputi mengamati, menanya, mengumpulkan data, mengasosiasikan dan mengkomunikasikan.

\section{DAFTAR PUSTAKA}

Abdul Majid. 2014. Pembelajaran Tematik Terpadu. Bandung: PT. Remaja Rosdakarya

Bimo Walgito. 2010. Pengantar Psikologi Umum. Yogyakarta: Andi Offset

Masri Singarimbun. 1989. Metode Penelitian Survey. Jakarta: LP3ES

Muhammad Hosnan. 2014. Pendekatan Saintifik dan Kontekstual dalam Pembelajaran Abad 21. Bogor: Ghalia Indonesia

Ridwan Abdullah Sani. 2014. Pembelajaran Saintifik untuk Implementasi Kurikulum 2013. Jakarta: Bumi Aksara.

Slameto. 2011. Belajar dan Faktor-faktor yang mempengaruhinya. Jakarta: Rhineka Cipta.

Sugiyono. 2012. Metode Penelitian Kuantitatif, Kualitatif dan R\&D. Bandung: Alfabeta.

Supardi. 2011. Dasar-dasar Ilmu Sosial. Yogyakarta: Penerbit Ombak.

Trianto. 2010. Model Pembelajaran Terpadu. Jakarta: Kencana.

Wibowo. 2013. Perilaku dalam Organisasi. Jakarta: PT. Raja Grafindo Persada.

Zamroni. 2011. Dinamika Peningkatan Mutu. Yogyakarta: Surya Sarana Grafika. 